\title{
MACROSPATIAL ANALYSIS OF EARLY SCYTHIAN FORTIFIED SETTLEMENTS IN THE RIGHT-BANK OF UKRAINE
}

\begin{abstract}
The macrospatial analysis of fortified settlements in the right-bank of Ukraine allows for observations of a few regularities related to the location of sites along the rivers and watersheds. 'Land' settlements, e.g. Yakushyntsi or Mlynok, may have connected sites located along large watercourses, e.g. Trakhtemyriv, Rudkivtsi, which specialised in trade with the Greeks.
\end{abstract}

ABSTRACT

Key words: macrospatial analysis, fortified settlements, Podolia, Scythian time, Early Iron Age

INTRODUCTION

In total 31 early Scythian fortified settlements were recorded in the right-bank of Ukraine (Fig. 1; Tab. 1). Of all the presented macro-scale spatial demarcation of sites, the most useful systematics is the one developed by Y. Boltryk [1993], in which it was proposed to connect settlements into groups formed by 'political alliances'. These alliances were formed between communities inhabiting settlements in order to exchange information about possible dangers and to aid each other in

\footnotetext{
* Institute of Archaeology, Adam Mickiewicz University, Umultowska 89D, 61-614 Poznań, Poland, e-mail: m.lawniczak88@gmail.com

** Institute of Archaeology, Adam Mickiewicz University, Umultowska 89D, 61-614 Poznań, Poland, e-mail: ignaczak@amu.edu.pl
} 


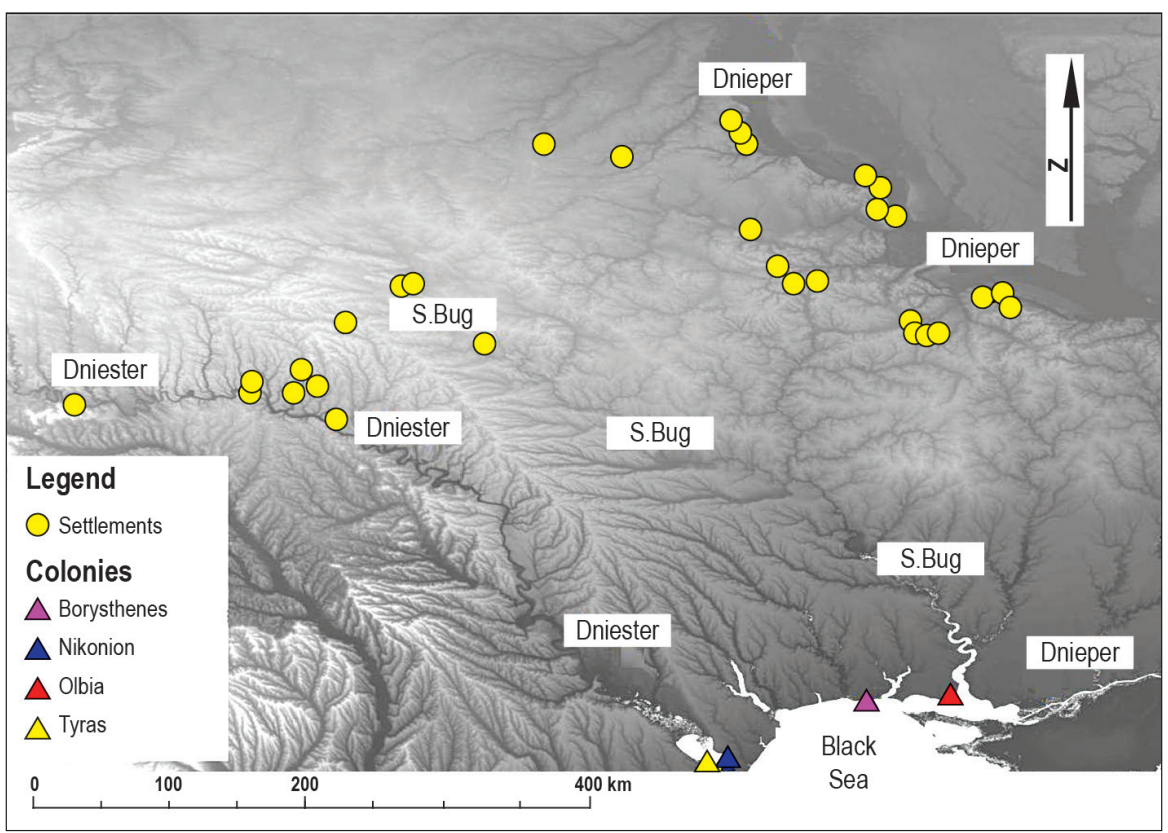

Fig. 1. Distribution of fortified sites in the right-bank Ukraine and Greek colonies connected with the zones. Author's work

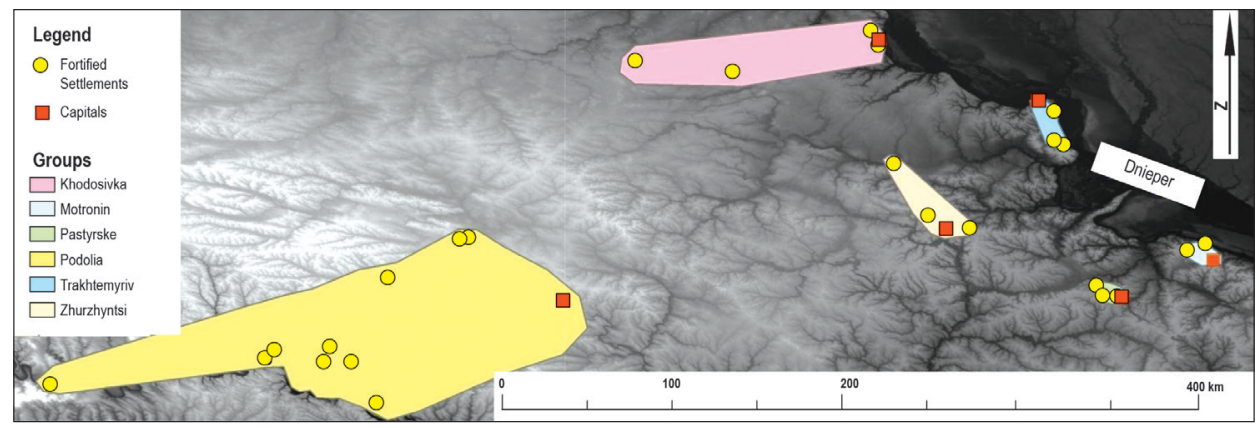

Fig. 2. Visualisation of the group division proposed by Y. Boltryk with a highlighted position of the central fortified settlements. Source: Boltryk 1993

defensive efforts. Y. Boltryk proposed five such settlement concentrations: Pastyrske, Tiasmin, Kaniv-Trakhtemyriv, Khotiv-Khodosiv and Zhurzhyntsi-Medvyn-Komariv. As the list of sites is incomplete, the initial proposition was further expanded, in order to implement concentrations from Nemyriv, Severynivka and Ilintsi in eastern Podolia. 


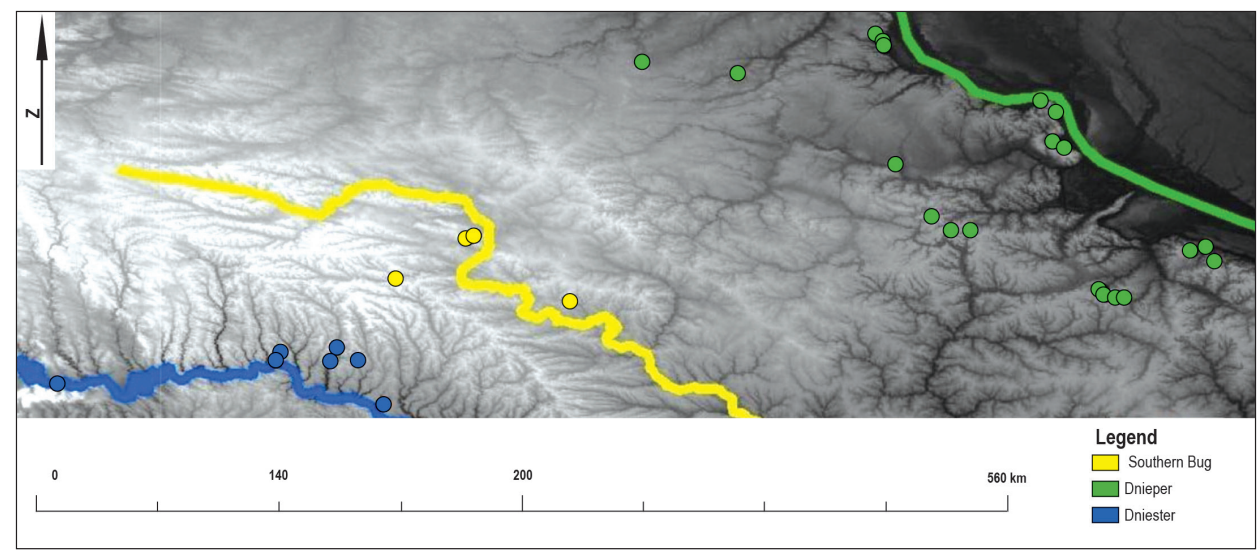

Fig. 3 . Representations of sites in relation to Dnieper, Southern Bug and Dniester. Source: Author's work

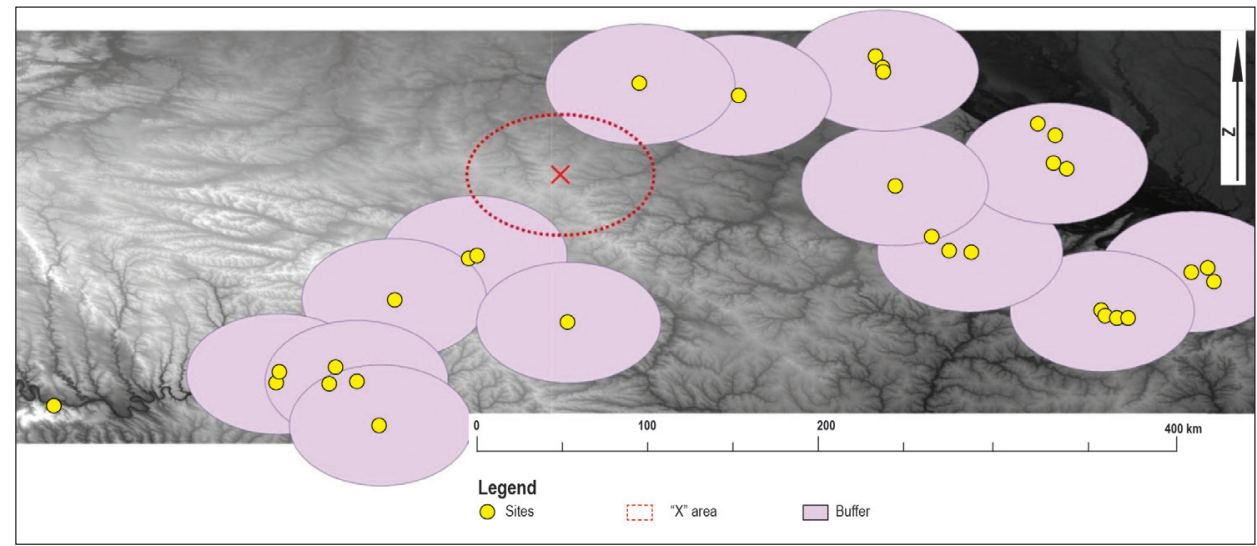

Fig. 4. Visualisation of land connections based on $35 \mathrm{~km}$ buffer-zones. 'X' marks the area, which should have a site sealing the assumed communication network. The farthest south western point is Rukhotyn, which lacks a connection with any of the settlements in the $70 \mathrm{~km}$ radius. Source: Author's work

Due to the increasing data, this initial division requires further development, modifications and detailed descriptions. For the purpose of the analysis, the author assumed that every designated group should comprise a single 'gigantic' site (with the size exceeding $100 \mathrm{ha}$ ), which is treated as an assumed 'capital city' - central settlement. The exception was the settlement in Pastyrske, which was to be surrounded by a rampart connecting all sites into one large concentration. After the analysis of the map illustrating the systematic of Y. Boltryk (cf. Fig. 2) it is clear 


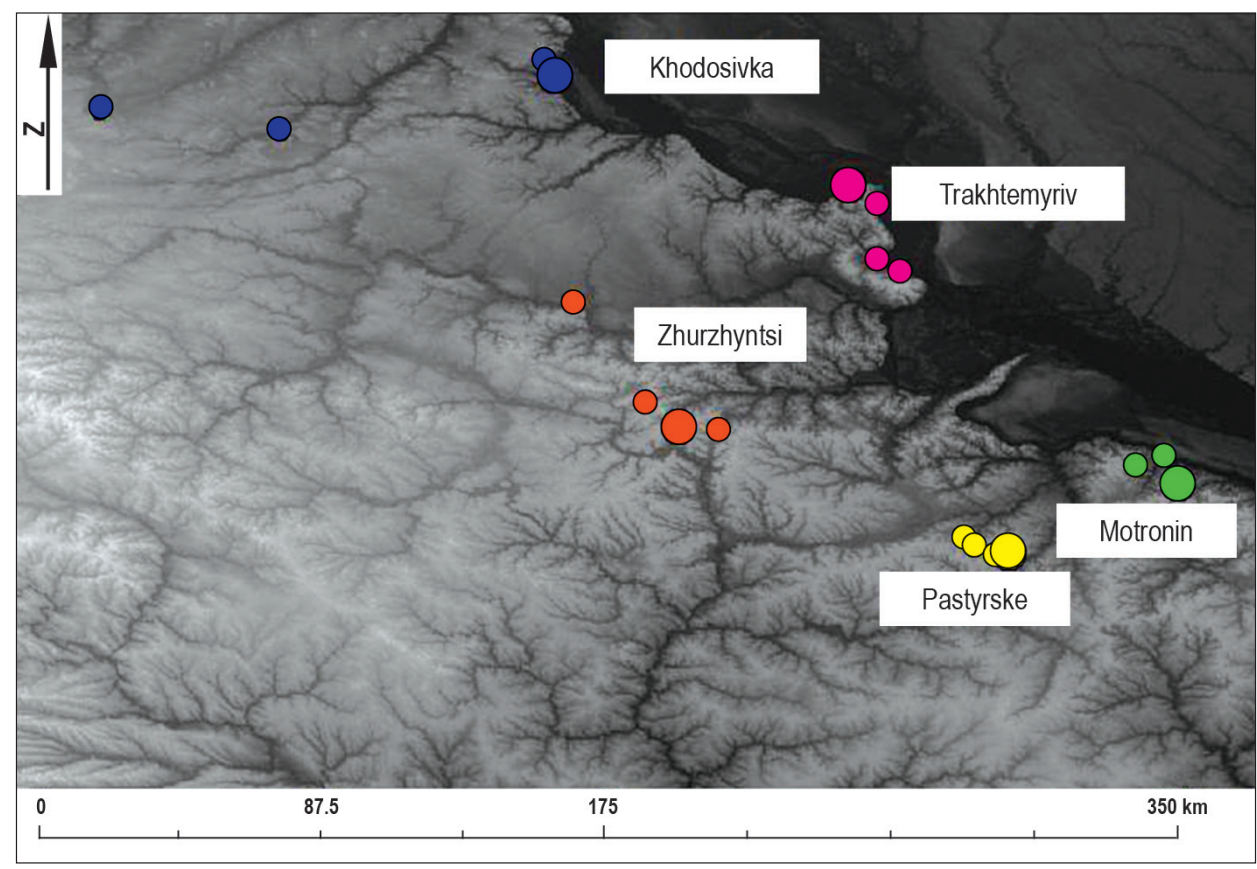

Fig. 5. Groups of sites associated with the Dnieper with highlighted 'capital cities'. Source: Author's work

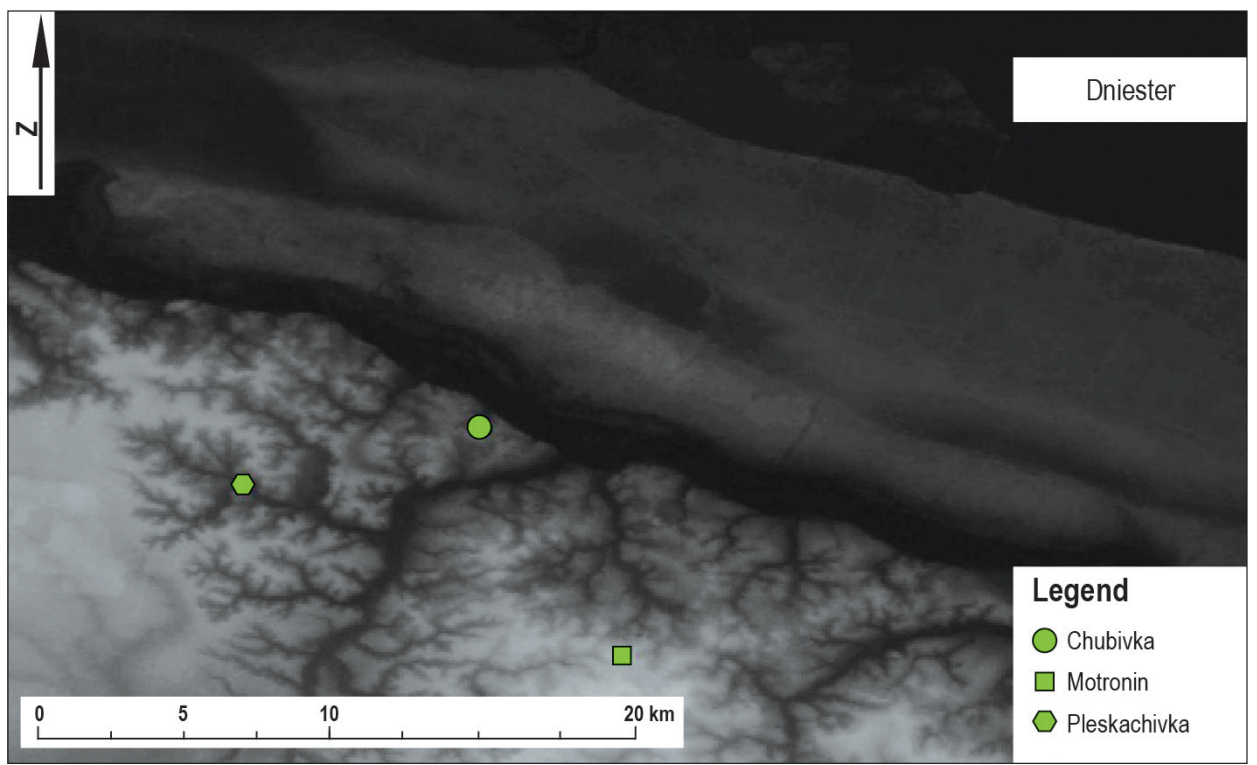

Fig . 6. Site distribution of sites of the Motronin sub-group. Source: Author's work 


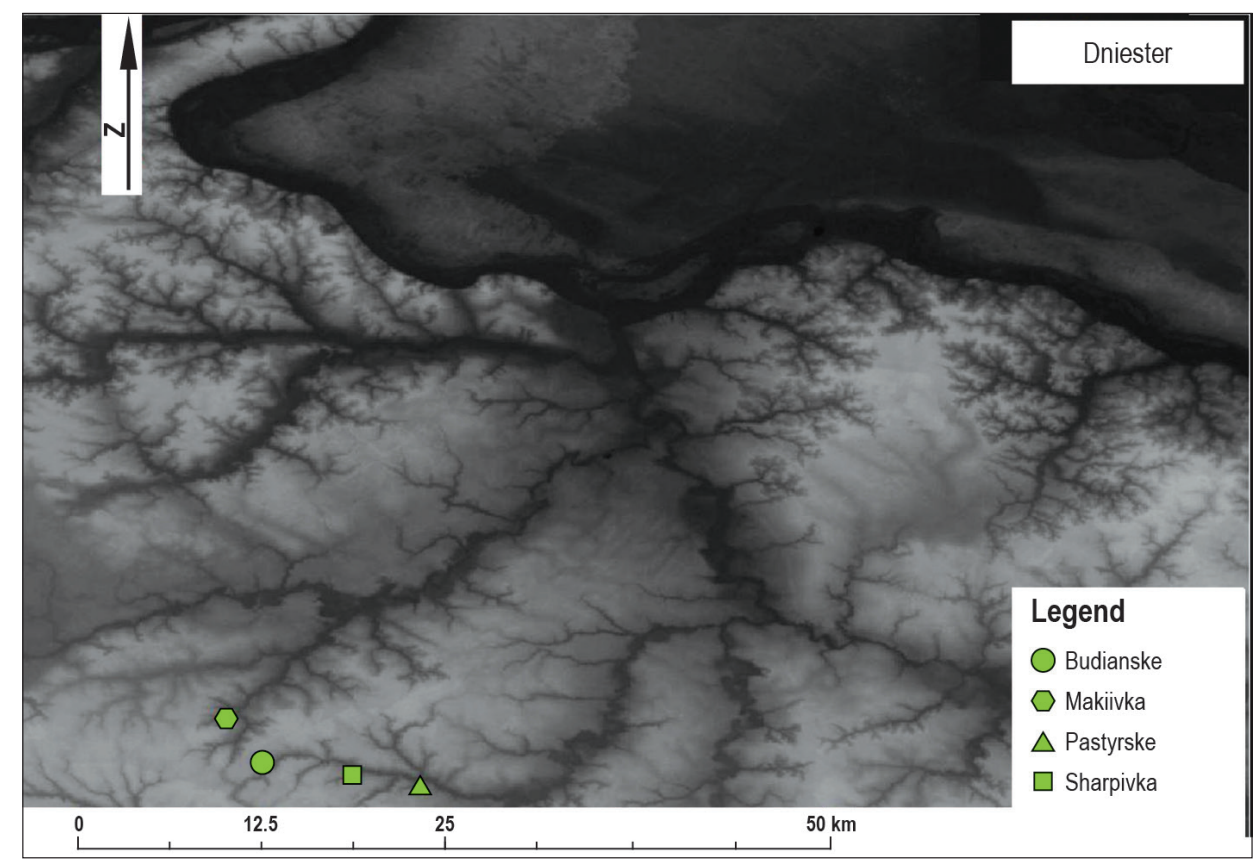

Fig. 7. Site distribution of the Pastyrske sub-group. Source: Author's work

that the size of the Podolia group is disproportionate in relation to other groups covering the area that connect all of the groups of the right-bank Ukraine. Remarkably, all fortified settlements were located in the vicinity of three large rivers: Dnieper, Southern Bug and Dniester, or their tributaries (cf. Fig. 3). Despite this, all groups display strong connections with the Dnieper River, apart from the Podolia group, which was located in the Southern Bug and Dniester catchment area. The distribution of particular fortified sites in this group shows that the sites are located over the Dniester along other rivers, contrary to the sites found in the Southern Bug area. In the remaining cases, the location of the fortified sites was determined by watersheds not by access to a nearby river. Such a thesis would imply their relation with land trails. It demonstrates, that there is no single factor that determined the location of the sites.

This argumentation proves, that the initial systematics of Y. Boltryk requires modifications, which would include an overriding class of settlement concentration (hereinafter referred to the 'group'). Its definition would be determined by a geographic factor - namely the vicinity of a river - and the internal division would use the existing model (identifying sub-groups). This solution would result in the division of the Podolia group into Dniester and Southern Bug groups with the remaining settlements being incorporated into the Dnieper group (Fig. 3). 


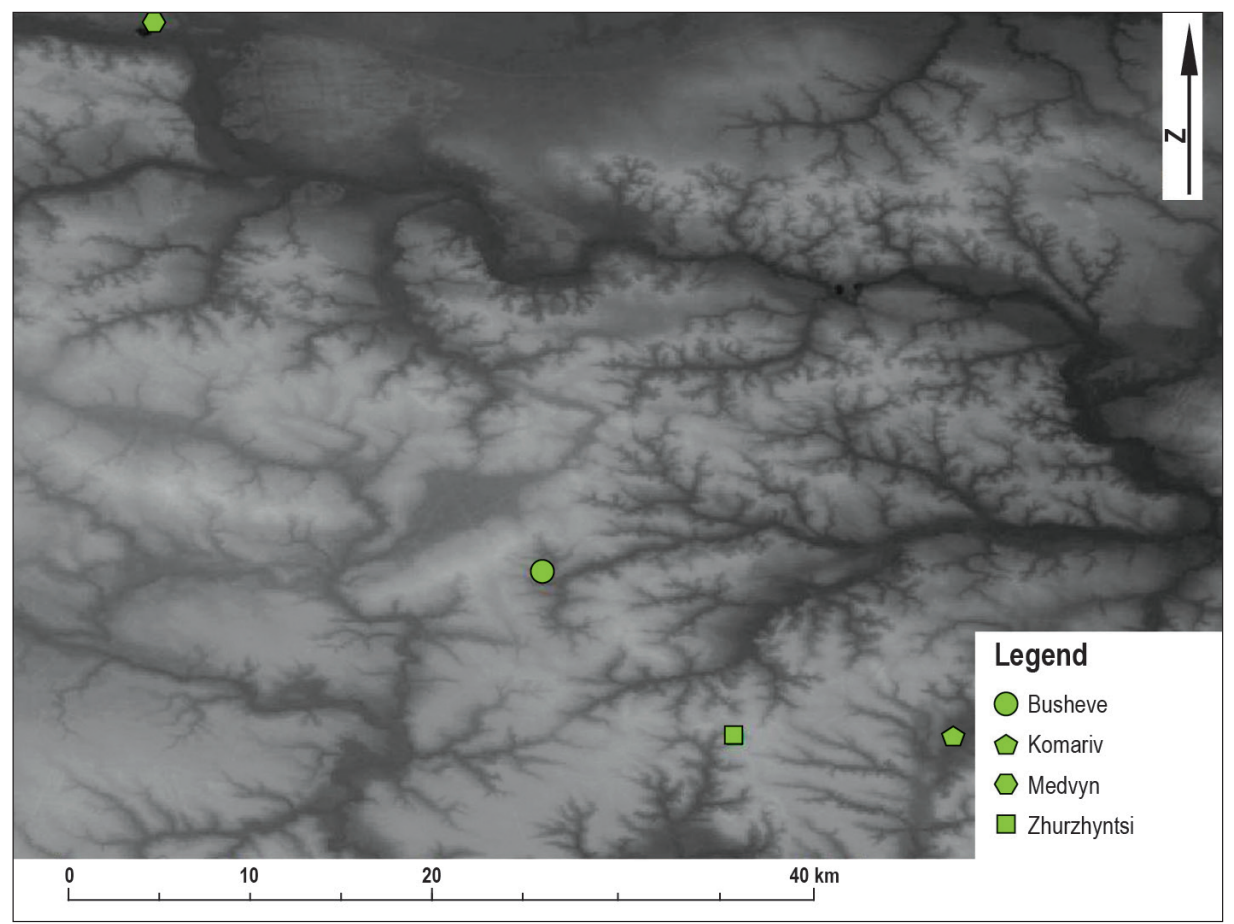

Fig. 8. Sites distribution of sites of the Zhurzhyntsi sub-group. Source: Author's work

The remaining part of the text will provide a detailed description of all groups, including the possible functions of all the settlements. It was assumed that the standard function of the settlements was to protect the population and to serve as a trade and political centre oriented towards the production and acquisition of goods (i.a. metallurgy, antler and bone processing, pottery manufacturing, textile production, agriculture, husbandry).

Location of the site was recognised as the specialising criterion, since the sites located along water trails (mainly Dnieper and Dniester, maybe partially Southern Bug) were connected with Greek colonies, while the sites located along land trails were using other means of communication between the sites within a particular structure (for nomads - Scythians). In addition, an important element of a site location was the influence and military control over the goods distributed along trails.

By using the 'Buffer' tool in ArcMap software a $35 \mathrm{~km}$ long buffer zone was drawn around the settlements (Fig. 4). As a result, a network of fortified settlements set $70 \mathrm{~km}$ apart was designated. In order to travel such a distance, a slightly laden rider (e.g. a Scythian) would need a single day, while a cart or a walker would need two days. The two locations are: exceptional area marked on the map 


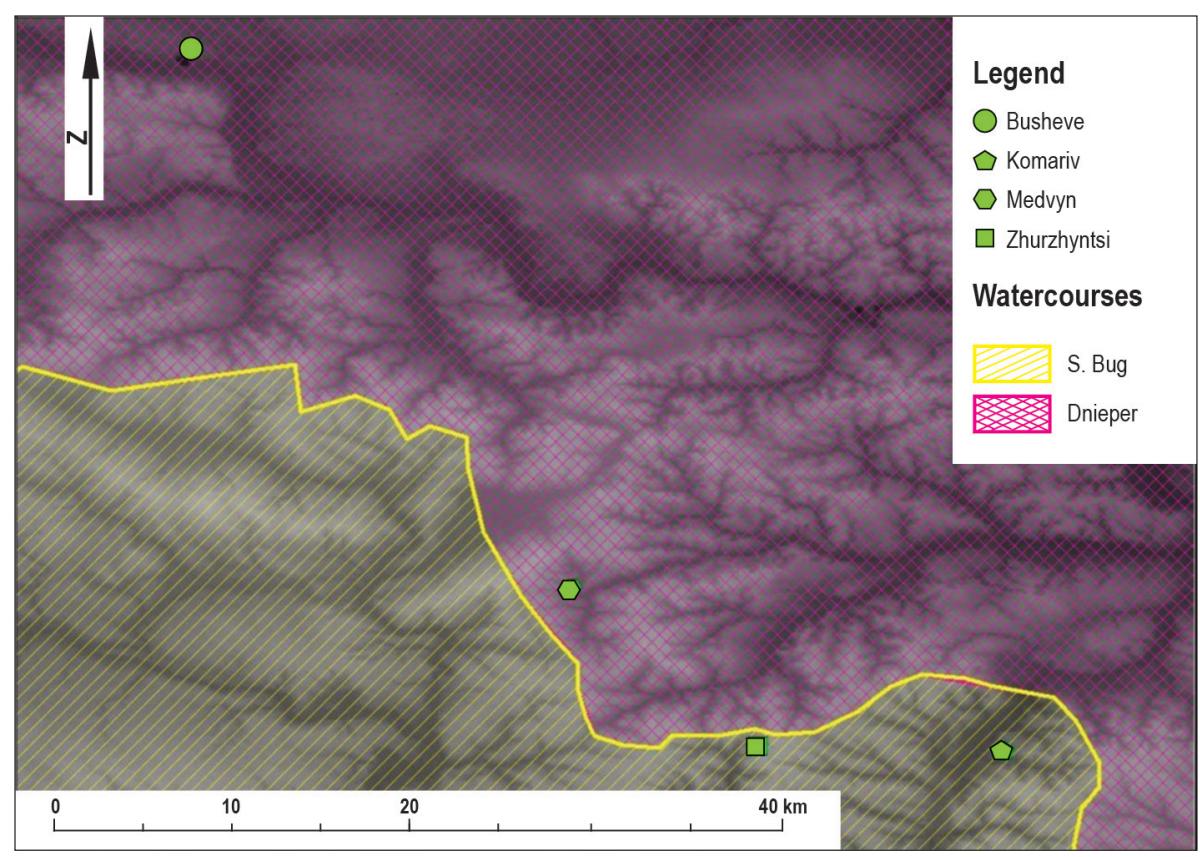

Fig. 9. Site distribution of sites of the Zhurzhyntsi sub-group in relation to the Dnieper River and Southern Bug. Source: Author's work

as X (Fig. 4), in which (or its direct vicinity) no settlement dated to the Scythian period was found (although its remains might have been destroyed or there was a smaller, open settlement) and the second location the Rukhotyn in the west (Fig. 4). What makes it unique is its location on the margin of the area.

\section{THE DNIEPER GROUP OF THE EARLY SCYTHIAN FORTIFIED SETTLEMENTS}

Considering the size of the fortified settlements, it is safe to assume that the majority of the population inhabiting it was living in the vicinity of Dnieper (i.e. the Khodosivka Welyke - 2000 ha) and to the east of it (i.e. the Bilsk settlement - $4500 \mathrm{ha}$ ) [Ławniczak 2013]. The majority of them probably served as a trade post collecting neighbouring resources (i.e. wood, wheat, or cattle), which would be transported by tributaries to the Dnieper River from where a developed river 


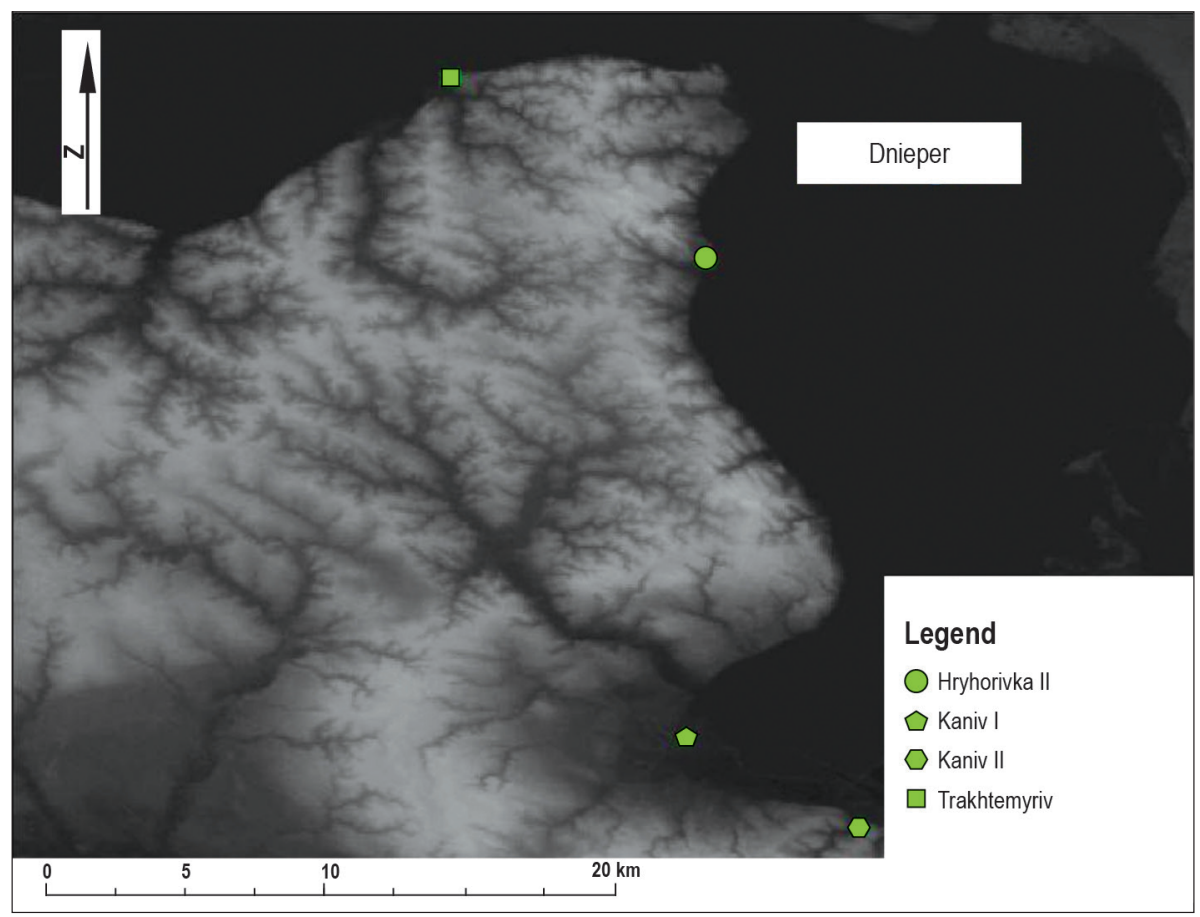

Fig. 10 . Site distribution of sites of the Trakhtemyriv sub-group. Source: Author's work

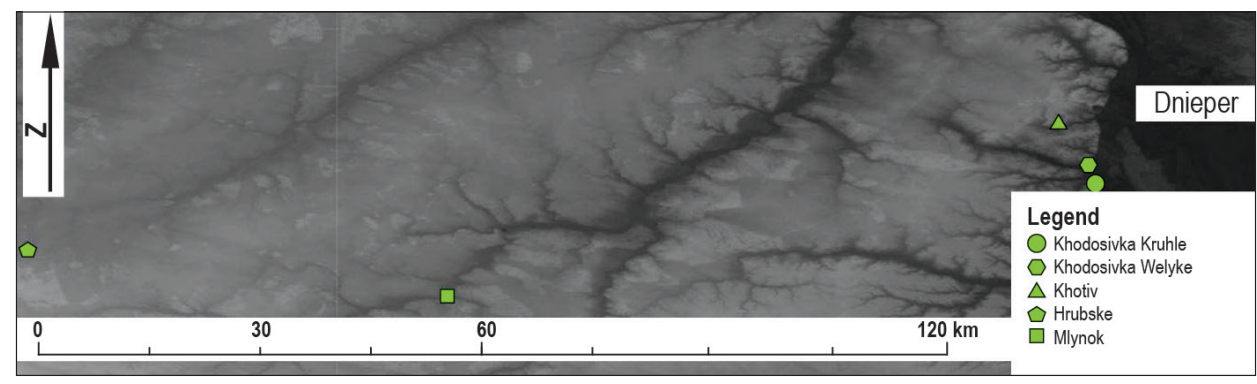

Fig . 11. Site distribution of the Khodosivka sub-group. Source: Author's work

transport would ship them to the Greek colonies, e.g. Borysthenes (the Greek name of the Dnieper River), located at the Black Sea coast. According to the outlined proposition, this group comprises five sub-groups, which are named after the 'capital' settlement, i.e. Motronin, Pastyrske, Zhurzhyntsi, Trakhtemyriv, and Khodosivka (Fig. 5). 
This concentration comprises of three settlements and of a few flat settlements. These settlements are the farthest ones in the East of all the sites found on the right-bank of the Dnieper River. The main settlement is Motronin, which covers an area of 200 ha, with the remaining two being Chubivka and Pleskachivka. They are all located a few kilometres away from the Dnieper River (Fig. 6). The Motronin settlement is the furthest to the South, located on the Kholodnyi Plateau in the centre of the Kholodnyi Yar area.

This sub-group comprises of four settlements (Pastyrske, Makiivka, Budianske, Sharpivsk), located close to each other (Fig. 7). The greatest distance between the settlements is $9 \mathrm{~km}$ (Pastyrske - Makiivka). There is a thesis, that during their existence there was a rampart surrounding four settlements. This is supposed to explain the absence of a gigantic site exceeding 100 ha, since the Pastyrske site covers ‘only' 25 ha [Boltryk 1993].

\subsection{THE ZHURZHYNTSI SUB-GROUP}

This concentration comprised of four fortified sites: Zhurzhyntsi, Komariv, Medvyn and Busheve (Fig. 8). The largest one is Zhurzhyntsi which is over 700 ha. The group is located between the rivers Ros and Hnylyi Tikych, on the watershed between Dnieper and Southern Bug (Fig. 9) [Ławniczak 2013: 52]. Such a distance between the main watercourses (Dnieper and Southern Bug) and the location on the watershed suggests, that this settlement is connected with land trails. Through the analysis of land connections (Fig. 4) it is possible to treat it as a link between concentrations in the south-east (Motronin, Pastyrske), east (Trakhtemyriv) and north (Khodosivka) of the Dnieper River drainage. This thesis is supported by the far north location of the settlement in Busheve $(31 \mathrm{~km}$ from the closest in Medvyn), which closed the trade routes. 


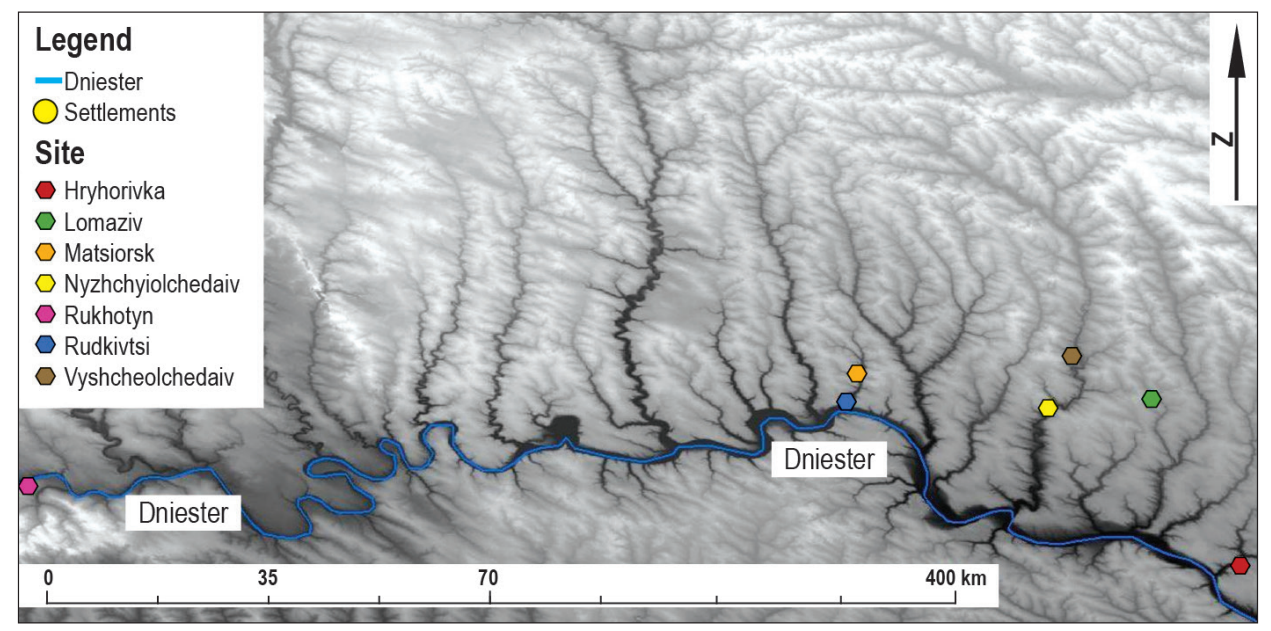

Fig. 12. Site distribution of sites in the Dniester drainage. Source: Author's work

1.4. THE TRAKHTEMYRIV SUB-GROUP

This sub-group comprises of four fortified sites (Trakhtemyriv, Hryhorivka, Kaniv I and Kaniv II) and is located on a massive elevation on the Dnieper River curve, referred to in the literature as the promontory (partially also in its vicinity; Fig. 10). The name of the concentration comes from the site covering an area of 630 ha and its location on a tall steep, which goes down to the Dnieper River itself. The positioning of this place, in the vicinity of a river may suggest a strong relationship of the group with the assumed water trails, and it might be further supported by the distance from main watersheds and the location on the side of the network of connections presented in the beginning of this chapter.

\subsection{THE KHODOSIVKA SUB-GROUP}

This concentration consists of five fortified settlements (Khodosivka Welyke, Khodosivka Kruhle, Khotiv, Hrubske and Mlynok), is located the farthest to the north of all of the described sub-groups (Fig. 5). Khodosivka Welyke is the largest settlement located in the right-bank Ukraine, with a size of approx. 2000 ha and is located on the outskirts of present-day Kyiv, which stresses the importance of the area for locating large-size settlements. Two further settlements (Khodo- 


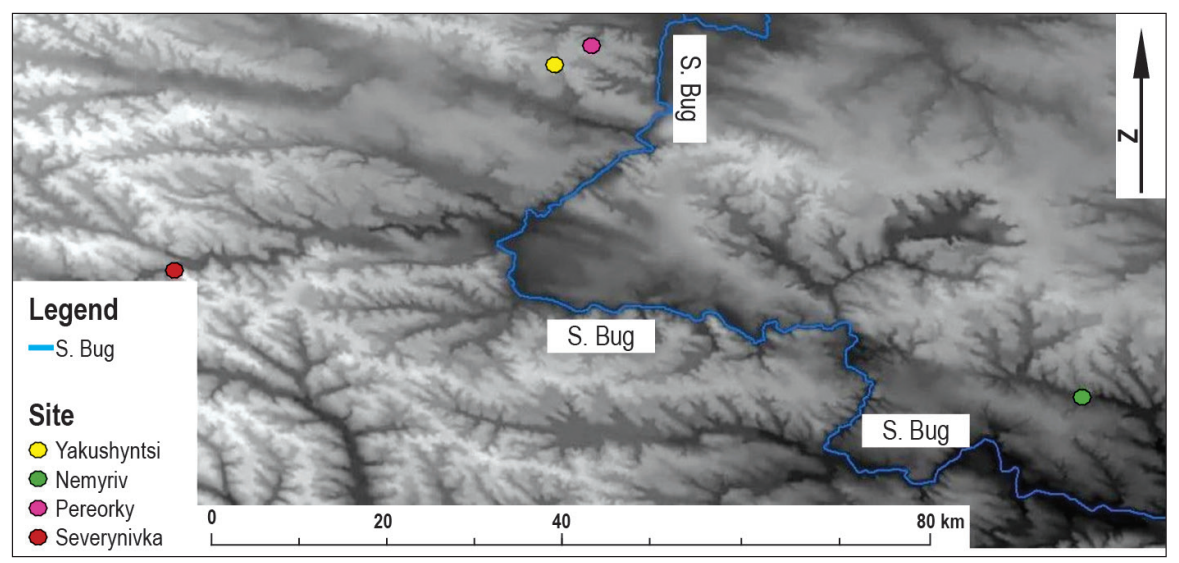

Fig. 13. Site distribution of sites in the Southern Bug drainage. Source: Author's work

sivka Kruhle and Khotiv) were located within a short distance (a few kilometres) from the central one. The three settlements were most likely connected with the Dneper River and used it for communication with other sites (Fig. 11). On the opposite side, there are two sites of the group located to the west (Hrubske and Mlynok), which might have been connected with the land trail joining all the Dnieper River sites with the Southern Bug and Dniester groups (Fig. 4).

\section{THE DNIESTER GROUP OF EARLY SCYTHIAN FORTIFIED SETTLEMENTS}

Judging by the arrangement of sites in the vicinity of Dniester, its local settlements were of a similar function to the Dnieper River ones but of adequate proportions (smaller number and size of settlements, as well as a smaller river). In this case the main colonies associated with the trail were Tiras (from the Greek Dniester) and Nikonion located at the Dniester estuary (Fig. 1). Probably their role was not limited to trade posts but also meant the responsibility for controlling the river trail and participation in contacts between Greeks and the communities inhabiting the western areas such as the Vekerzug culture located in the Tisza drainage [Chochorowski 2014]. In total, the Dniester group included seven settlements: Hryhorivka, Lomaziv, Vyshcheolchedaiv, Nyzhchyiolchedaiv, Matsiorsk, Rudkivtsi and Rukhotyn. Remarkably, there is no dominating centre, that would exceed the others in size. Nearly all sites were located on the left (northern) bank of 


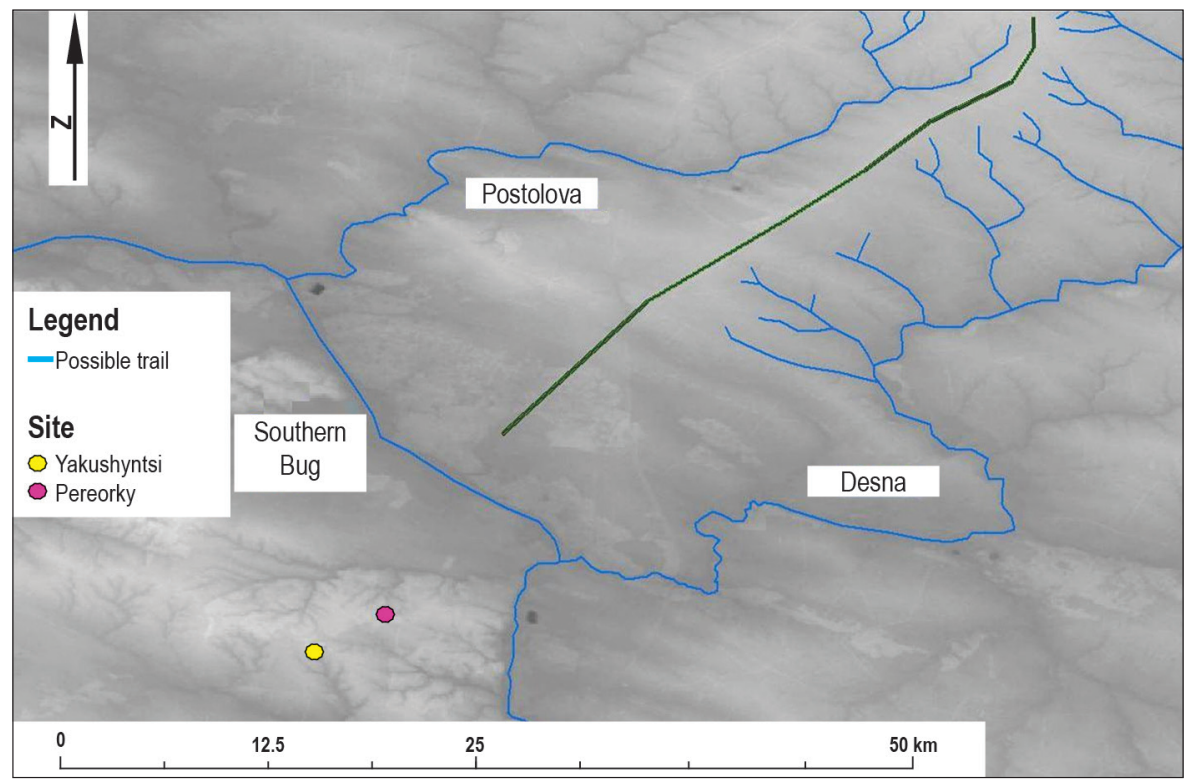

Fig. 14 . Hydrologic system and the possible trail around the fortified settlement in Pereorky and Yakushyntsi. Source: Author's work

Dniester, which probably indicates the neutral boarder of Scythians and the lands under their control. The exception is Rukhotyn, located in the far west. All sites of this group are located with in a small distance from Dniester (max. $24 \mathrm{~km})$ and its tributaries (Fig. 12).

3. THE SOUTHERN BUG GROUP OF EARLY SCYTHIAN FORTIFIED SETTLEMENTS

In comparison to two other concentrations (the Dnieper and Dniester ones), the Southern Bug group is the one most strongly associated with land (Fig. 13). Out of four constituting sites (Pereorky, Yakushyntsi, Severynivka, Nemyriv), three are located on watersheds and may have contributed to the mainland communication network between Dnieper and Dniester (Fig. 4). The exception is Nemyriv, which is in the lower part of Southern Bug, on the side of the assumed land trail. Due to its size (125 ha) it contrasts strongly with other Podolian sites, being the only large settlement in the area. 
Pereorky, Yakushyntsi, and Severynivka are the three settlements strongly associated with watersheds. The first two are in close vicinity of each other $(4 \mathrm{~km})$ on a plateau located on the right-bank of Southern Bug (Fig. 13). On the other side of the river, there are, two smaller watercourses: Postolova (in the north) and Desna (in the south) $18 \mathrm{~km}$ apart from each. Perhaps this watercourse served as a land trail leading from the Dnieper River (through fortified settlements in Hrubske and Mlynok) to the Dniester (Fig. 14), which contirbuted to their significance for the previously highlighted network of land connections (Fig. 4). The area may also served as a crossing of the Southern Bug, which may have been protected from the south-west by two fortified settlements, forming a gateway towards the ford and an entrance on the trail. This thesis is supported by strongly fortified settlement in Yakushyntsi. $35 \mathrm{~km}$ away from the south-east of the site in Yakushyntsi, also on the right tributary of Southern Bug is Severynivka. The fortified settlement is located at the intersection of two vital watersheds, the first, aligned along the north-eastern/south-western axis, serves as the aforementioned connection for structures located over the Dnieper with the sites over the Dniester, and the second one starts at the Black Sea, aligned along the north-east/south-west axis, between the catchment area of Dniester and Southern Bug (Fig. 13). The thesis regarding large land movement around the site is supported by finds recovered during archaeological research conducted by a joint Polish-Ukrainian expedition between 2009 and 2015. The registered trails of local antler and bone processing, as well as numerous fragments of horse cheek pieces (finished, unfinished, or repaired). They prove that workshop producing objects used for horse-riding existed there. It can be assumed that it was often used for repairing or replacing horse-riding equipment, which would further suggest that the settlement was involved in servicing land trails.

3.2. NEMYRIV

Nemyriv is clearly the largest and most eastward located fortified settlement of Podolia. It is the single located on the left Southern Bug bank, away from the largest watersheds in the area, hence way from the mainland trails (Fig. 13). The size of the settlements, its seclusion and location in the lower part of the river, in relation to the rest of the group, as well as the large number of Greek amphorae and other 
Hellenic imports found [Smirnova 1996] indicate the openness of the settlement towards trade with the ancient world. The lack of competitive sites of similar sizes might suggest that the area within the influence zone was extremely extensive. The interpretative challenge is imposed by the present-day character of the Southern Bug, which can be sailed only up to $150 \mathrm{~km}$ from the estuary, while the distance from Nemyriv measures approx. $400 \mathrm{~km}$. It remains plausible that due to a different climate, the water levels in the period from the $7^{\text {th }}$ to $5^{\text {th }}$ century BC were sufficient for sailing the Southern Bug yet this hypothesis needs to be verified.

CONCLUSIONS

The macrospatial analysis of fortified settlements in the right-bank of Ukraine allows observation of a few regularities related to the location of sites along the rivers and watersheds. 'Land' settlements, e.g. Yakushyntsi or Mlynok, which may have connected sites located along large watercourses, e.g. Trakhtemyriv, Rudkivtsi, specialised in trade with the Greeks. The initial results of the archaeological research show that some of the sites located near the rivers (Nemyriv, Motronin) have a higher frequency of Greek imports than fortified settlements located on the watersheds (Severynivka), which confirms the abovementioned thesis. The entire system and network of connections, provide insight into some certain, perhaps even planned actions, which cannot be narrowed down to coincidence.

T a b l e 1

List of fortified settlements in the right-bank of Ukraine

\begin{tabular}{|c|c|c|c|c|}
\hline $\begin{array}{l}\text { Name } \\
\text { (Ukrainian name) }\end{array}$ & $\begin{array}{l}\text { Group } \\
\text { (Sub-group) }\end{array}$ & Size & Location & Reference \\
\hline 1 & 2 & 3 & 4 & 5 \\
\hline $\begin{array}{l}\text { Budianske } \\
\text { (Будянське } \\
\text { городище) }\end{array}$ & $\begin{array}{l}\text { Dnieper } \\
\text { (Pastyrske) }\end{array}$ & N/A & $\begin{array}{l}\text { Cherkasy } \\
\text { Oblast, } \\
\text { Smila Raion }\end{array}$ & Boltryk 1993 \\
\hline $\begin{array}{l}\text { Busheve } \\
\text { (Бушевське } \\
\text { городище) }\end{array}$ & $\begin{array}{l}\text { Dnieper } \\
\text { (Zhurzhyntsi) }\end{array}$ & 4 ha & $\begin{array}{l}\text { Kyiv } \\
\text { Oblast, } \\
\text { Rokytne Raion }\end{array}$ & $\begin{array}{l}\text { uk.wikipedia.org/Wiki/ } \\
\text { Бушевське_городище. } \\
20.06 .2013\end{array}$ \\
\hline $\begin{array}{l}\text { Chubivka } \\
\text { (Чубівське } \\
\text { городище) }\end{array}$ & $\begin{array}{l}\text { Dnieper } \\
\text { (Motronin) }\end{array}$ & N/A & $\begin{array}{l}\text { Cherkasy } \\
\text { Oblast, } \\
\text { Cherkasy Raion }\end{array}$ & Boltryk 1993 \\
\hline
\end{tabular}




\begin{tabular}{|c|c|c|c|c|}
\hline $\begin{array}{l}\text { Name } \\
\text { (Ukrainian name) }\end{array}$ & $\begin{array}{l}\text { Group } \\
\text { (Sub-group) }\end{array}$ & Size & Location & Reference \\
\hline 1 & 2 & 3 & 4 & 5 \\
\hline $\begin{array}{l}\text { Hrubske } \\
\text { (Грубське } \\
\text { городище) }\end{array}$ & $\begin{array}{l}\text { Dnieper } \\
\text { (Khodosivka) }\end{array}$ & N/A & $\begin{array}{l}\text { Zhytomyr } \\
\text { Oblast, } \\
\text { Korostyshiv } \\
\text { Raion }\end{array}$ & Moruzhenko 1969 \\
\hline $\begin{array}{l}\text { Hryhorivka I } \\
\text { (Григорівське } \\
\text { городище) }\end{array}$ & Dniester & 10 ha & $\begin{array}{l}\text { Vinnytsia } \\
\text { Oblast, } \\
\text { Mohyliv Raion }\end{array}$ & Moruzhenko 1969 \\
\hline $\begin{array}{l}\text { Hryhorivka II } \\
\text { (Григорівське } \\
\text { городіще) }\end{array}$ & $\begin{array}{l}\text { Dnieper } \\
\text { (Trakhtemyriv) }\end{array}$ & N/A & $\begin{array}{l}\text { Cherkasy } \\
\text { Oblast, } \\
\text { Kaniv Raion }\end{array}$ & Boltryk 1993 \\
\hline $\begin{array}{l}\text { Yakushyntsi } \\
\text { (Якушинці) }\end{array}$ & Southern Bug & 12.5 ha & $\begin{array}{l}\text { Vinnytsia } \\
\text { Oblast, } \\
\text { Vinnytsia Raion }\end{array}$ & Moruzhenko 1969 \\
\hline $\begin{array}{l}\text { Kaniv I } \\
\text { (Канівське } \\
\text { городище) }\end{array}$ & $\begin{array}{l}\text { Dnieper } \\
\text { (Trakhtemyriv) }\end{array}$ & N/A & $\begin{array}{l}\text { Cherkasy } \\
\text { Oblast, } \\
\text { Kaniv Raion }\end{array}$ & Boltryk 1993 \\
\hline $\begin{array}{l}\text { Kaniv II } \\
\text { (Канівське } \\
\text { городище) }\end{array}$ & $\begin{array}{l}\text { Dnieper } \\
\text { (Trakhtemyriv) }\end{array}$ & N/A & $\begin{array}{l}\text { Cherkasy } \\
\text { Oblast, } \\
\text { Kaniv Raion }\end{array}$ & Boltryk 1993 \\
\hline $\begin{array}{l}\text { Khodosivka } \\
\text { Kruhle } \\
\text { (Ходосівське } \\
\text { Кругле } \\
\text { городище) }\end{array}$ & $\begin{array}{l}\text { Dnieper } \\
\text { (Khodosivka) }\end{array}$ & 1 ha & $\begin{array}{l}\text { Kyiv } \\
\text { Oblast, } \\
\text { Kyiv-Sviatoshyn } \\
\text { Raion }\end{array}$ & Hutsal 2000 \\
\hline $\begin{array}{l}\text { Khodosivka } \\
\text { Welyke } \\
\text { (Ходосівське } \\
\text { Вельике } \\
\text { городище) }\end{array}$ & $\begin{array}{l}\text { Dnieper } \\
\text { (Khodosivka) }\end{array}$ & $\begin{array}{l}\text { over } \\
2000 \text { ha }\end{array}$ & $\begin{array}{l}\text { Kyiv } \\
\text { Oblast, } \\
\text { Kyiv-Sviatoshyn } \\
\text { Raion }\end{array}$ & Hutsal 2000 \\
\hline $\begin{array}{l}\text { Khotiv } \\
\text { (Хотівске } \\
\text { городище) }\end{array}$ & $\begin{array}{l}\text { Dnieper } \\
\text { (Khodosivka) }\end{array}$ & 31 ha & $\begin{array}{l}\text { Kyiv } \\
\text { Oblast, } \\
\text { Kyiv-Sviatoshyn } \\
\text { Raion } \\
\end{array}$ & Pokrovskaya 1952 \\
\hline $\begin{array}{l}\text { Komariv } \\
\text { (Комарівське } \\
\text { городище) }\end{array}$ & $\begin{array}{l}\text { Dnieper } \\
\text { (Zhurzhyntsi) }\end{array}$ & N/A & $\begin{array}{l}\text { Cherkasy } \\
\text { Oblast, } \\
\text { Kaniv Raion }\end{array}$ & Boltryk 1993 \\
\hline $\begin{array}{l}\text { Lomaziv } \\
\text { (Ломазівське } \\
\text { городище) }\end{array}$ & Dniester & N/A & $\begin{array}{l}\text { Vinnytsia } \\
\text { Oblast, } \\
\text { Mohyliv Raion }\end{array}$ & Artamonov 1946 \\
\hline
\end{tabular}




\begin{tabular}{|c|c|c|c|c|}
\hline $\begin{array}{l}\text { Name } \\
\text { (Ukrainian name) }\end{array}$ & $\begin{array}{l}\text { Group } \\
\text { (Sub-group) }\end{array}$ & Size & Location & Reference \\
\hline 1 & 2 & 3 & 4 & 5 \\
\hline $\begin{array}{l}\text { Matsiorsk } \\
\text { (Маціорське } \\
\text { городище) }\end{array}$ & Dniester & N/A & $\begin{array}{l}\text { Khmelnytskyi } \\
\text { Oblast, } \\
\text { Nova Ushytsia } \\
\text { Raion }\end{array}$ & Moruzhenko 1969 \\
\hline $\begin{array}{l}\text { Makiivka } \\
\text { (Макіiвске } \\
\text { городище) }\end{array}$ & $\begin{array}{l}\text { Dnieper } \\
\text { (Pastyrske) }\end{array}$ & $\mathrm{N} / \mathrm{A}$ & $\begin{array}{l}\text { Cherkasy } \\
\text { Oblast, } \\
\text { Smila Raion }\end{array}$ & Boltryk 1993 \\
\hline $\begin{array}{l}\text { Medvyn } \\
\text { (Медвин) }\end{array}$ & $\begin{array}{l}\text { Dnieper } \\
\text { (Zhurzhyntsi) }\end{array}$ & N/A & $\begin{array}{l}\text { Kyiv Olbast } \\
\text { Bohuslav Raion }\end{array}$ & Boltryk 1993 \\
\hline $\begin{array}{l}\text { Mlynok } \\
\text { (Млинок) }\end{array}$ & $\begin{array}{l}\text { Dnieper } \\
\text { (Khodosivka) }\end{array}$ & 50 ha & $\begin{array}{l}\text { Kyiv } \\
\text { Oblast, } \\
\text { Fastiv Raion }\end{array}$ & Daragan 2010 \\
\hline $\begin{array}{l}\text { Motronin } \\
\text { (Мотронінське } \\
\text { городище) }\end{array}$ & $\begin{array}{l}\text { Dnieper } \\
\text { (Motronin) }\end{array}$ & 200 ha & $\begin{array}{l}\text { Cherkasy } \\
\text { Oblast, } \\
\text { Chyhyryn Raion }\end{array}$ & Daragan 2010 \\
\hline $\begin{array}{l}\text { Nemyriv } \\
\text { (Немирівське } \\
\text { городище) }\end{array}$ & Southern Bug & $125 \mathrm{ha}$ & $\begin{array}{l}\text { Vinnystsia } \\
\text { Oblast, } \\
\text { Nemyriv Raion }\end{array}$ & Daragan 2010 \\
\hline $\begin{array}{l}\text { Nyzhchyiolchedaiv } \\
\text { (Нижчий } \\
\text { Ольчедаїв) }\end{array}$ & Dniester & $\mathrm{N} / \mathrm{A}$ & $\begin{array}{l}\text { Vinnytsia } \\
\text { Oblast, } \\
\text { Mohyliv Raion }\end{array}$ & Artamonov 1946 \\
\hline $\begin{array}{l}\text { Pastyrske } \\
\text { (Пастирське } \\
\text { городище) } \\
\end{array}$ & $\begin{array}{l}\text { Dnieper } \\
\text { (Pastyrske) }\end{array}$ & 25 ha & $\begin{array}{l}\text { Cherkasy } \\
\text { Oblast, } \\
\text { Smila Raion }\end{array}$ & Yakovenko 1968 \\
\hline $\begin{array}{l}\text { Pereorky } \\
\text { (Переорки) }\end{array}$ & Southern Bug & N/A & $\begin{array}{l}\text { Vinnytsia } \\
\text { Oblast, } \\
\text { Vinnytsia Raion }\end{array}$ & Moruzhenko 1969 \\
\hline $\begin{array}{l}\text { Pleskachivka } \\
\text { (Плескачевське } \\
\text { городище) }\end{array}$ & $\begin{array}{l}\text { Dnieper } \\
\text { (Motronin) }\end{array}$ & N/A & $\begin{array}{l}\text { Cherkasy } \\
\text { Oblast, } \\
\text { Smila Raion }\end{array}$ & Boltryk 1993 \\
\hline $\begin{array}{l}\text { Rudkivtsi } \\
\text { (Рудковецьке } \\
\text { городище) }\end{array}$ & Dniester & 40.5 ha & $\begin{array}{l}\text { Khmelnytskyi } \\
\text { Oblast, } \\
\text { Nova Ushytsia } \\
\text { Raion }\end{array}$ & Hutsal 2000 \\
\hline $\begin{array}{l}\text { Rukhotyn } \\
\text { (Рухотінське } \\
\text { городище) }\end{array}$ & Dniester & 40 ha & $\begin{array}{l}\text { Chernivtsi } \\
\text { Oblast, } \\
\text { Khotyn Raion }\end{array}$ & Moruzhenko 1969 \\
\hline
\end{tabular}




\begin{tabular}{|l|l|l|l|l|}
\hline $\begin{array}{l}\text { Name } \\
\text { (Ukrainian name) }\end{array}$ & $\begin{array}{l}\text { Group } \\
\text { (Sub-group) }\end{array}$ & Size & Location & Reference \\
\hline $\mathbf{1}$ & $\mathbf{2}$ & $\mathbf{3}$ & $\mathbf{4}$ & $\mathbf{5}$ \\
\hline $\begin{array}{l}\text { Severynivka } \\
\text { (Северинівське } \\
\text { городіще) }\end{array}$ & Southern Bug & 5.5 ha & $\begin{array}{l}\text { Vinnytsia } \\
\text { Oblast, } \\
\text { Zhmerynka } \\
\text { Raion }\end{array}$ & Shelekhan 2011 \\
\hline $\begin{array}{l}\text { Sharpivka } \\
\text { (Шарпівське } \\
\text { городище) }\end{array}$ & $\begin{array}{l}\text { Dnieper } \\
\text { (Pastyrske) }\end{array}$ & 15 ha & $\begin{array}{l}\text { Cherkasy } \\
\text { Oblast, } \\
\text { Smila Raion }\end{array}$ & Daragan 2010 \\
\hline $\begin{array}{l}\text { Trakhтетугіv } \\
\text { (Трахтемирівське } \\
\text { городище) }\end{array}$ & $\begin{array}{l}\text { Dnieper } \\
\text { (Trakhtemyriv) }\end{array}$ & 630 ha & $\begin{array}{l}\text { Cherkasy } \\
\text { Oblast, } \\
\text { Kaniv Raion }\end{array}$ & Fialko, Boltryk 2003 \\
\hline $\begin{array}{l}\text { Vуshсhеоссhеdaiv } \\
\text { (Вищеольчедаїв) }\end{array}$ & Dniester & N/A & $\begin{array}{l}\text { Vinnytsia } \\
\text { Oblast, } \\
\text { Mohyliv Raion }\end{array}$ & Artamonov 1946 \\
\hline $\begin{array}{l}\text { Zhurzhуntsi } \\
\text { (Журжиніецьке } \\
\text { городище) }\end{array}$ & $\begin{array}{l}\text { Dnieper } \\
\text { (Zhurzhyntsi) }\end{array}$ & 700 ha & $\begin{array}{l}\text { Cherkasy } \\
\text { Oblast, } \\
\text { Lysianka Raion }\end{array}$ & Bushyn, Scherbatiuk 2004 \\
\hline
\end{tabular}

Description:

1 - first column contains names presented in Ukrainian literature (in brackets);

2 - second column - location of fortified settlement according to the group;

3 - third column - size of fortified settlement;

4 - fourth column - location of fortified settlements according to the administrative division;

5 - fifth column - source of information about the site. 


\section{REFERENCES:}

Artamonov M.I.

1946 Arkheologicheskie pamiatniki Yuzhnoy Podolii (po materialam Yugo-Podolskoy ekspeditsii) (held in archives of IA NANU). Kyiv.

Boltryk Y. V.

1993 Osnovni skupchennia poselenskykh struktur v Serednomu Prydniprovyi Doslidzhennia starozhytnostey Ukrayiny. In: Tezy dopovidey naukovoyi konferentsiyi Muzeyu istorychnykh koshtovnostey Ukrayiny - filialu Natsionalnoho muzeyu istoriyi Ukrayiny, 35-48. Kyiv.

Bushyn M.I., Scherbatiuk V.M.

2004 Spilka "Vytoky" u kraeznavchomu rusi Ukrayiny: dosiahnennia i perspektyvy. In: Uporiadnyk, 102-107. Cherkasy.

Chochorowski J.

2014 Scytowie a Europa Środkowa - historyczna interpretacja archeologicznej rzeczywistości. Materiały i Sprawozdania Rzeszowskiego Ośrodka Archeologicznego XXXV: 9-59.

Daragan M.N.

2010 Geoinformatsionnyi analiz transformatsii poselencheskikh struktur $w$ nachale rannego zheleznogo veka $v$ Srednem Podneprove: sostoyanie problem i perspektivy issledovaniya (held in archives of IA NANU).

Fialko O.E., Boltryk Y.V.

2003 Napad skifiv na Trakhtemyrivske horodysche. Kyiv.

Hutsal A.F.

2000 Rudkovetske horodyshche i pershyi pokhid skifiv u prydnistrovskyi lisostep. In: Davnia i serednovichna istoriya Ukrayiny, 69-93. Kamianets-Podilskyi.

Ławniczak M.

2013 Grodziska wczesnoscytyjskie prawobrzeżnej Ukrainy. Zagadnienia ewidencji oraz systematyki (held in the archives of Adam Mickiewicz University). Poznań.

Moruzhenko A.O.

1969 Horodyshcha skifskoho chasu na teritoriyi lisostepu Skhidnoyi Yevropy. Visnyk Kharkivskoho universytetu 3: 65-73. 
Pokrovskaya E.F.

1952 Khotivske horodyshche. Arkheolohichni pamiatki URSR 4: 12-20. Kyiv.

Shelekhan O.V.

2011 Oboronni sporudy Severynivskoho horodyshcha skifskoho chasu v baseyni r. Pivdennyy Buh. Mahisterium (Arkheolohichni studiyi) 45: 55-59.

Smirnova G.I.

1996 Nemirovskoe gorodishche - obshchaya kharakteristika pamiatnika VII-VI vv. do n.e. Arkheolohiya 4: 67-84.

Yakovenko E.V.

1968 Pastyrske horodyshche skifskoho chasu. Arkheologiya 21: 175-186. 
